U. S. Goological Survev.

Reports, open-file, no. 440. 1958. 
U. S. Geological Survey.

Reports, Open-file, no. 440, 1958. 
Borate Deposits of the Mojave Reglon, Calfforniad

By

Wand $c^{\circ} \sin 1$ th

U. S. Ceologlcal Survey

Claremont, Californis

U. S. Ceological Survey

PENN FILE REPORT

This report is preliminary and has

not been edited or reviewed for

conformity with Geological Survey

standards or nomenclature.

I This article is essentially the same as a talk presented at the Annual Neeting of the Colorado Nining Association at Denver, Colorado, February 2, 1958. 
Abstract . . . . . . . . . . . . . . . . . . . . . 3

Introduction. . . . . . . . . . . . . . . . . . . . . . . . 4 4

Uses of boron and borates . . . . . . . . . . . . . . 5

Products of boron users . . . . . . . . . . . . . 6

Commercial campounds of boron . . . . . . . . . . . . . 7

Boron minerals. . . . . . . . . . . . . . . 8

Production in the United States................... 10

World cccurrences. . . . . . . . . . . . . . . . . . . . 11

Thet.......................... 11

Italy; Germany; Russia; Australia; Asia . . . . . . . . . . 12

South America. . . . . . . . . . . . . . . . . . 13

U. S. Borate Deposits. . . . . . . . . . . . . . . . . . . 14

Ceneral features. . . . . . . . . . . . . . . . . 15

Searles Lake example . . . . . . . . . . . . . . . . . . . . 17

Results of basin drilling . . . . . . . . . . . . . 22

Kramer District example. . . . . . . . . . . . . . . . . . . . 23

Results of drilling near Kramer... . . . . . . . . . . 25

Outlook for new discoveries. . . . . . . . . . . . . . . . . . 26

References... . . . . . . . . . . . . . . . . . . . . 27 


\section{Borate Deposits of the Mojave Region, Callfornia}

By

Werd C. Snith

Abstract

Cutput of the United States borate producers reached approximately $1,000,000$ tons in 1957 , nearly four t1mes the average annual production of 1941-45. Increasing consumption for long-established uses and several new ones accounts for the rise; further rise, for new uses such as hich energy fuels, lies ahead. Among know borate deposits, the largest are at Searles Lake and Kramer, which supply 90 percent of the world's recorded production. The Kramer ore body, which is very laree, consists of remarkably pure sodium borates in Tertiary lake beds. At Searles Lake, also large, the borax is produced from brines pumped out of salt layers which are the residue of a dessicated Plelstocene lake. Prospecting for borates is now more active than it has been for years. The best prospecting ground is in the alluvial-covered basins of western Nevada and part1cularly southesstern Callfornia, in concealed sections of Tertiary continental sediments. Several playas or salt flats that resemble Searles Lake were test-drilled for the U. S. deologlcal Survey by contractor but the holes encountered no borates. Dr1ll holes near Kramer, however, encountered a deposit of colemanite in lake beds. 


\section{Introduction}

During recent years, a number of newspaper and azine articles have discussed possible new uses of boron. In July 1957 defense agencles ennourced that certain manufacturing plants producing "high energy" fuels for w...tiary alrcreft were being enlarged, and that in these fuels the main components are hydrogen and boron. Flve years earlier, in 1952, the U. 3. Cological Survey began an investigation of the domestic deposits of borate minerals. This was at the request of the U. S. Nary, Bureau of Aeronautics. Since 1952, therefore, the geology of borate deposits, and many of their spectal aspects, have been studied by alzable group of geologists, mineralogists, and other special1sts of the Ceological Survey. This report contains terial gathered by our group efforts. Naturally, I would like to acknowledge here the contributions of all who have been active in the group, and I regret that it 1s impractical to c1te each of them by name. 
The producers of boron supply a broad market, beceuse the consumers of boron compounds are spread widely in our economy. Individuals use boron in borax soap powders, in common household borax, and in the boronbearing gasoline recently marketed in several parts of the country. Industrial users take large quant1t1es; the glase manufacturers, for example, consume about a fourth of the production. Most individuals ao not realize that a great number of things fumiliar to them require boron compounds for their manufacture or processing. A few typical products listed below bring out the importance of boron in dasly 11 fe. 
Products of boron users

Inàustry

Consuner Products

Ceramics

Glass making

Metal products

Agriculture, forestry

Industrial Products
Typical products

Soeps

Pharmaceuticals

"Boron gasoline"

Glazed ware of all kinds

Enamels on metals

Automoblle headlight unlts

Fiber glass

Optic glasses

Heat-resisting glass ("Pyrex")

Fluxing compounds

De-oxidizing compounds

Mold retardant in food processing

Trace element in fertilizers

Weed killers

Insecticides

Fire retardant

Leather preservat1ve

Paper glaze component

Abrasives 
Boron enters comerce most1y sodfum borate--borax and anhydrous borax-and as boric ac1d. Chemical composition and $\mathrm{B}_{2} \mathrm{O}_{3}$ content of these compounds are as follows:

Principal commercial boron compounds

\begin{tabular}{lllcc}
\hline Commercial name & Chemical name & $\begin{array}{c}\text { Chemical } \\
\text { composition }\end{array}$ & $\begin{array}{c}\text { Boron content } \\
\text { percent } \\
\text { B }\end{array}$ & $\begin{array}{c}\text { percent } \\
\mathrm{B}_{2} \mathrm{O}_{3}\end{array}$ \\
\hline Borax & $\begin{array}{l}\text { Sodium borate } \\
\text { (decahydrate) }\end{array}$ & $\mathrm{Na}_{2} \mathrm{~B}_{4} \mathrm{O}_{7} \cdot 10 \mathrm{H}_{2} \mathrm{O}$ & 11.3 & 36.5 \\
Anhydrous borax & $\begin{array}{l}\text { (Sodium borate } \\
\text { (anhydrous) }\end{array}$ & $\mathrm{Na}_{2} \mathrm{~B}_{4} \mathrm{O}_{7}$ & 21.5 & 69.1 \\
Borlc acid & Borlc ac1d & $\mathrm{B}(\mathrm{OH})_{3}$ & 17.5 & 56.3 \\
\hline
\end{tabular}

Users also obtain boron in a wide variety of other forms, ranging from elemental boron to organic compounds. The producing companies have large chemical plants and research staffs and the 11st of their products is always increasing. 


\section{Boron minerals}

The boron minerals of greatest economic importance in the United Btates are borax, ulexdte, and colemanite. Thelr chemical relationahips are indicated by listing them, with some minor minerals, crouped by composition. (See also Palache and others, 1951, p. 320-21). The List does not include hydrated borates of calclum-magnesium and magneslum, which are major minerals in deposits elsewhere in the warld but found only in small amounts in domest1c depos1te, nor does $1 t$ include other borates of less importance.

Principal hydrated borate minerals

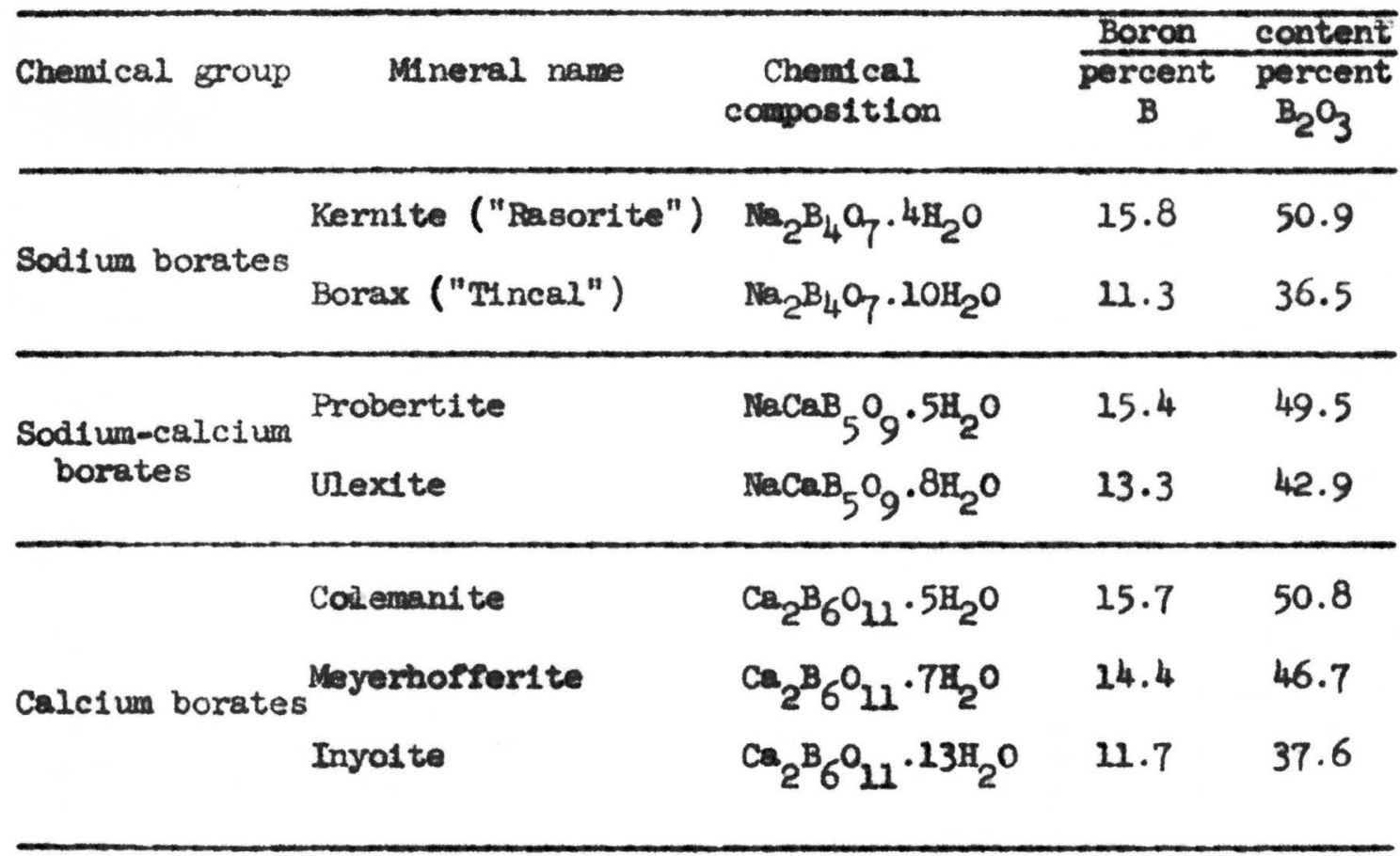


Among the merals, borax is especially important. Borax was the first borate mineral mined in the United States--in 1864 at Borax Laike, California, north of San Francisco. (Fur details of the history of borax production in the Unlted States, see Hanks, 1883, and Ver Planck, 1956). Prom 1872 to 1890, both borax and ulexite were mined from the efrlorescences in the salt flats, or "borate marshes", of western Nevada and southeastern Californ1a. Next, colemanite became the leading borate mineral as mining moved from the rsh deposits to the Tertiary bedded deposits in the hills. Since 1927, borax has been dominant. It is the ore mineral at Kramer, the leading domestic producer, and it is also comnon to speak of borax at Searles lake, though aining there consists of punping brines that contain the sodium borate in solution, along with potash and other valuaible components. 


\section{Production in the United States}

Domestic production of borate minerals has been rising steeply for several years because of steady increases in established uses and the development of new uses other than military. The use of boron in hifh energy fuels has not yet had a significant effect on domestic production. Rounded figures for domest1c production, which has come entirely from southeastern Californie, are as fallows (Axundale, 1956, p. 139; Calif. Div. Mines, 1958, p. 8-9):

Period

$1941-45$ (average)

1946-50 (average)

1951-55 (average)

1956

1957 (estimated)
Production per year

(tons of borates)

273,000

500,000

730,000

944,950

$1,000,000 ?$

According to the latest authorltat1ve elgures, which are for 1956, when 944,950 tons were produced, our damst1c borate product1on was valued at $\$ 39,591,953$. The indicated average valu-about $\$ 40$ per ton-Is the price at the producing plants in Callfornit. 


\section{World Occurrences}

A few notes on world production of borates will give additional background to our picture of our domestic industry. We do not have reliable flgures for world production, because certain countries do not release figures. We belleve that the United States, which exports from a fifth to a fourth of its production, has been supplying the world with about 90 percent of its requirement for some thirty years.

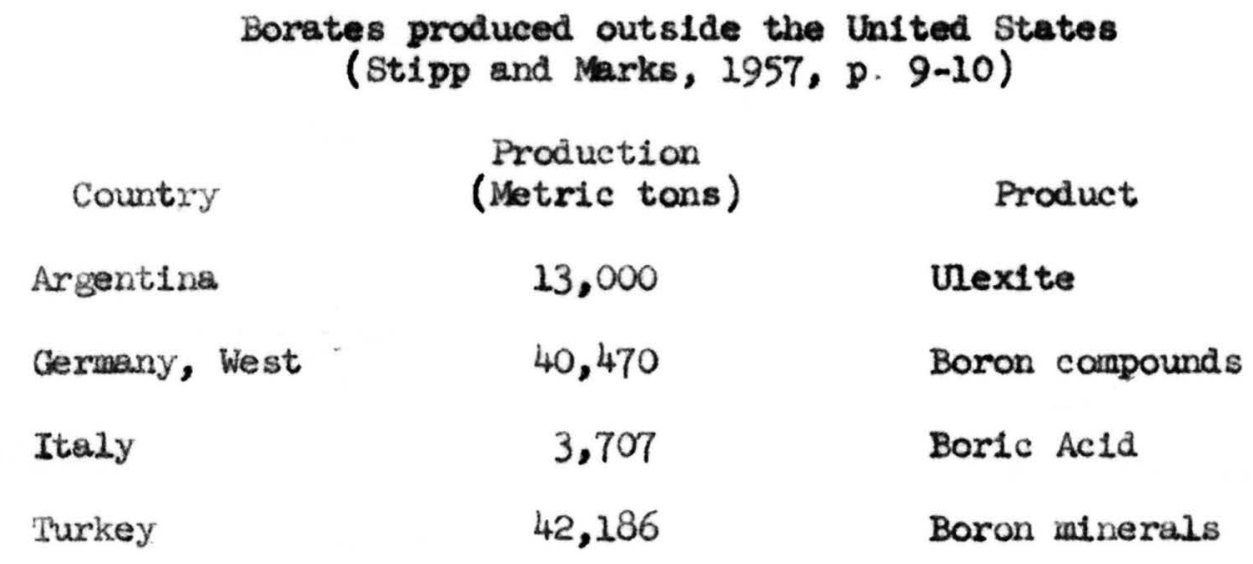

A few highlights of the occurrence and production of borates outside of the United States follow. (See also Anonymous, 1933, p. 20-44). Tibet and nearby parts of the high region north of India contain borate deposits that are noted as the world's first important source of borax for commerce. Carried to Europe at first by caravan, beginning about 2250 (the time of Marco Polo), the borax from Mibet was the chief supply until about the middle of the 19th century. The deposits are little known, and they must be small. Their geologie types seem to include hot-spring aprons and desert basin salines. 
Italy developed a small but steady production in the middle of the 19th century, and displaced the supply from Tibetan sources. The striklng feature of the Italian production, which still continues, is Its source: The boron is recovered from steam and hot water poured out of fumarolic vents in Tuscany. The waters yield boric acid $\mathrm{B}(\mathrm{OH})_{3}$. (The mineral of this camposition is sassolite).

In Cermany, at the famous Stassfurt locality, the marine sediments of Permian age that are mined mainly for potash, also yield some borate (hydroboracite, $\mathrm{CaMgB} 6 \mathrm{O}_{11} \cdot \mathrm{H}_{2} \mathrm{O}$ ).

The Russians produce borax in the region of the Inder Lake, in western Kazakhstan. The quantity produced is not reported, but it appears to be large enough to meet the needs of the country. Mineralogic reports (Godlevsky, 1937, p. 315-368) ind1cate that there are deposits of several kinds. The primary deposits are in Permian marine sediments. These contributed boron to more valuable secondary accumulations in (Tertiary?) continental deposits, and also to the brine of a salt lake.

Turkey has produced minor quantities of borate for years. After a decrease in production of pricelte $\left(\mathrm{Ca}_{4} \mathrm{~B}_{10} \mathrm{O}_{19} \cdot 7 \mathrm{H}_{2} \mathrm{O}\right.$ ) (see Palache and others, 1.951, p. 341-343) from the well-known local1ty near Panderma, with exhaustion of the deposit there, new production came frok a nearby deposit discovered in 1951. In the new deposits, the chlef borate is colemanite, but they include other borates (Meixner, 1953, p. $86-92)$. 
Australia and Asia (other than Tibet, mentioned above) seem to lack borates. Africa also 18 lacking, so far as production records go, though possibly borates occur in potash prospects in Eritrea, tested by Italians in the early 1930's.

When we consider South America's borates along with those of the United States, we realize that the western hemisphere is vell endowed with known, usable deposits. Borates are found in a number of extensive salt flats ("salares") In the dry basins of the Andes of Argentina, Chile, Bolivia and Peru (Miller and Singewald, 1919; Singewald, 2943). It is interesting to know that South Amertca also has, in addition to the "salare" type of borates, a few bedded deposits in Tertiary continental sediments. One contains kernite, the sodium borate long known only at Kramer (Ahlfeld and Angelell1, 1948; Muesig and Allen, 1957, p. 426-437).

The borates produced from some of the South American salares were most important in world trade in the latter part of the 19th century, but exports shrank as Callfornie production became dorainant. Today a few locallties produce small quantitles, used for nat1onal consumption. Most of the South American deposits are unworked because their grade is low, or because their location, remote from world markets, makes the cost of transportation high. 
U. S. borate deposits

A noteworthy feature of the borate Industry in the United states, Is that the steadily rising demands for borte raw materials are met mainly by two sources of supply in southeastern Callfornia: the Kramer dstrict, which supplies two-thlids or more of the production, and Bearles lake. Other districts contribute only minor quantities. Nost amalier depositis have been lale ever since the two b1g sources came Into full production, about 1927, and prospectors have had 11ttle reason for persisting in a search for new borate deposits. In the Last two years or so, hovever, lnterest in prospecting has misen perceptibly, and In January 2957, flve holes were arilled in the Kramer district to test for borates. 


\section{General Features}

The known borate deposits of the United States geographically are limited to California, western Nevade, and southern Oregon. Practically all the springs and wells known to contain more boron than average surfece waters are limited to the same area. We assume these surface occurrences reflect the presence of subsurface rocks that contain, and yield to the surface more boron than generally found in the earth's crust. It seems likely that the boron content of the subsurface rocks of the boron-bearing province need be only slightly higher than the figure computed as the average in the earth's crust, 3 parts per milI1on (Mason, 1952, p. 41).

In geologic mode of occurrence, our domestic borate deposits of comercial value (past or present) are essent1ally saline materials, accumulated with other continental sediments within basins of interior drainage. A major essential process in the concentration of soluble constituents in such basins is desiccation. The process bullds accumulations within periods of time that are gelogdcally rather short. 
In geologic age, the borate accumulations range from Recent back Whrough the Tert1ary at least as far as middle Mocene, perhaps farther. The oldest deposits may be as old as Cretaceous; they consist of bedded colemanite in non-fossiliferous beas in Clark County, near Las Vegas, Hevada (Iongwell, 1949, p 935). The Calico Nountalns colemanite deposits are well-dated as mid-Miocene (Lewis, G. E., written commun1cation, 1954). The colemanite-ulexite deposits of the Furnace Creek district, Death Valley, are probably Pliocene (Noble, 1941, p. 954-956), and the Kramer deposit is probably Pliocene (Cale, 1946, p. 335) also. The Searles Lake brine and salt layers are of Quaternary age; the upper part rests on mud layers which are 25,000 to 10,000 years old, according to $\mathrm{C}^{14}$ determinations (Libby, 1954, p. 739). 


\section{Searles Iake example}

Searles Iake is interesting both as a very large mineral deposit and as an example of what surface processes can do to concentrate rafnor ecmponents and put them in reach of profltable extraction. The Searles Lake borax is produced, along with several coproducts, from brines pumped out of two porous bodies of erystalline salt that underlie a salt flat In brief, these crystaline salt bocies and their en losed brines are the residues of vater which, during late Plelstocene time, entered the basin from a long drainage, essentially that of the owens River (Gale, H. S., 1914, p. 251-323). 
Some figures make the size of the Searles Iake deposit tangible. About 12 square miles of salt are exposed in the middle of the basin, and about 27 more square miles at the margin are covered by several feet of slope wash. The exposed salt is the top of an "Upper Salt Body", which has a maximum thickness of 95 feet; it rests on a "Parting Mud" layer, (about 15 feet thick) which in turn is underlain by a "Lower Salt Body" w1th a maximum thickness of 54 feet. The salt bodies are crystalline and they are layered. The doulnant saline mineral changes with depth, the sequence in the upper layering being halite, hanksite, and trona. With these minerals are other chloride, sulfate, and carbonate compounds of sodlum. Borax crystals and layers of borax form a minor part of the salt bodles; in aggregate, the solld borax contains more boron than is in the brine, but only brine is worked. The brine makes up 35 to 50 percent of the volume of the crystal bodies. On average it contalns about 1.0 percent $\mathrm{B}_{2} \mathrm{O}_{3}$; the total dissolved solids being 35 percent of the brine (Haines, D. V., and Smith, O. I., written communication, 1957 ). 
From data such as those just slven, the total boran content of Gearles Iake has been calculated from time to tim. A representative published figure is that of Turrentine (1926), who est1mated 17,350,000 tons of $\mathrm{B}_{2} \mathrm{O}_{3}$ in the brine and solld crystals of the "Upper Salt Body" wone. This, and all the assoclated suline merlal, is the concentrate erom a lake that began to recelve inflow (or a revived inflow), about 25,000 years ago. The date is besed on the determinations of $\mathrm{c}^{14}$ in the "Parting Mud" (Ifibby, 1954). The boran content of the Inflow 18 euggested by measurements of the dis8olved solids carried by the orrens River in recent, years. Reliable flgures (W1lcox, written communication 1946) indicate that the lower river carries about 700 tons of $\mathrm{B}_{2} \mathrm{O}_{3}$ per year. If this were the average for 25,000 years, the total would be 17,500,000 tons. This near colncldence with flgures above 18 accidental, because other factors must enter into a complete appraisal of innlow, but obviously the flgures involved are of the right onder of size. 
of special Interest and signiflcance is another result of the thorough search for boron in the Owens River and 1ts tributaries that was made 10 to 20 years ago (Wilcox, written communication, 1946). It was shown that nearly four-11fths of the boron that 18 now carried in the lower Owens RIver comes from on group of hot springs along Hot Creek, which is in the headwaters, near Mamoth lake and the Mono Craters. Analyses and stream measurements of these springs, made over a ten-year span (1936-1947), Indlcate that they supply water contalning 8 to 11 parts per million of boron. This is three or four times the average of the earth's crust. Presumably the springs pour out a mixture of surface water (no boron) and boron-bearing hot water. The ratio in the mixture is unknown. If we knew where the springs get thelr boron, wo would have this Beologlc story complete: Primary source, ore-forming fluid, processes of transport and deposition, and commerelel ore body. 
The foregalng account of Searles Laice ants some important parte of the story. It onits detalls of Plelstocene climatic changes, consequent changes of the rate of inflow to Soarles Lake, and balancing periods of desiccetion. Other interesting detalls relate to the fact that Searles Iaje besin is the mddale besln of a chnin of flve bandns. The basins upstream were cotchments for detritus and proliminary "treatment tanks", whIl those downstream took overflow when the Pleistocene lake stood at the raximum high-mter atrand (about 600 feet above the present salt flat). The general trend of longer campllcated treatment is to separate soluble salt from detritus and one salt frow another. The treatment may 180late materiels in separnte basine. Or, within a basin, the salts may becom sogregated (Imperfoctly) into successive layers, or 1nto zones distributed laterally from magin to center. 


\section{Results of basir. drilline}

W1th the Searles Lake deposit as an example of what might accumulate In a geologically short period of time, the U. S. Geological Survey tested the playas and salt llats in several besins in the Mojave region by drill1ng. The guides for grospecting seemed clear: (1) Select a salt flat or a dry lake with large dralnage area tributary to 1t, or with h1gh shore lines; (2) glve preference to a mamber of a chain of basins; (3) expect a lake salt to be flat-lying and wldespread (hence drill only one or two holes in a basin); (4) moderate depth is enough. (The survey holes were less than 1,000 feet deep, except one that was 1,070 feet). Test holes were drilled in elght basins that had never been tested adequately before. No new saline discoverles came from this group of holes, but they served to eliminate several basins from the class of "possible searles Lake" deposits. (For details, see Smith, G. I., and Pratt, W. P., 1957, and subsequent chapters of U. S. Ceological Survey Bullet1n 1045). 


\section{Kramer District example}

The Kramer ore body has been a challenge to geologlats and prospectors ever since it was discovered. The sirst discovery at Kramer was accidental; the calclum borate colemanite was struck In a well drilled for water in 1912. Further drilling, over a period of 15 years, revealed the main ore body, which eonsists of the sodium borates, borax and kernite. The borates are in lake beds that do not outcrop; they lie beneath younger sands and gravels, at depths of 150 to 1,100 feet. The lake beds are moderately t1lted and faulted. Some layers that are of mining thickness are nearly pure borax. The average grade of ore is not given elearly by Cale, but it seems to be high. The size of the ore body is very large. According to H. S. Cale (1946), the man ore underlies about 500 acres of ground, it 18 as auch as 150 feet thick, and 1t contains nearly $100,000,000$ tons of ore. 
The prospector who is attracted to the restern Mojave Desert by the example of Kramer flnds that the deposit lies in the middle of about 3,000 square miles of subdued topography of Basin and Range type. The U. 8 . Geological Survey studied the western Mojave in several ways: A bologic map was prepared in moderate deta1l, with special attention to the stratigraphy and structure of the Tertiary rocks. Ceophysics crews of the Survey made ground surveys with magnetic, selsmic, and (most effect1vely) gravimetric methods, to determine bedrock conf1guration below the basin fills. A large part of the area was surveyed with the alrborne megetometer, in search of structures bldden below alluvium. The oprings and wells were canvassed and sampled in search of traces of boron, as Indicator of concealed borates. With the geological surveys for background, three sites were selected for test arilling.

A map of the vicinity of Krwer currently being prepared by $T$. W. Dibblee and D. R. Mabey shows features of the geolosy and gravimetric data that are typical of the Nojave. Alluvium covers three-fourths of the ground, outcrops of the Tertiary rocks (whlch are expected to contain any borates that may exist) cover only tenth, and the remainder 1s pre-Tertiary crystalilne rocks. Bach site drilled under the direction of the Geological survey is on a block of ground selected because it is (1) near Kramer; (2) alluvial covered; (3) marised by Tertiary outcrops around the margins; (4) underlain, according to gravimetric and seimalc surveys, by a block of sediments and not by thin gravel on pediment on crystalilne rocks; (5) not adequately tested by previous drilling. 


\section{Results of drilling noar Kramer}

The results of the drilling are to be given in a report now being prepared for publication. The maln results are as follows. Hole 1 , south of Four Corners, and Hole 2, west of the Kramer deposit, proved to be barren of traces of borates. The results 11lustrate that a thick section of sediments is no guarentee thet borates will be found.

Holes 3, 4, and 5, wich l1e a mile apart along a north-south Ine about 8 miles east of the Kramer deposit, encountered the calc1um borate colemantte in lake beds at depths of 1,020 to 1,460 . The $\mathrm{B}_{2} \mathrm{O}_{3}$ content, in layers 2 feet or more thick, ranges from 7 to 20 percent. Colemanite was particularly abundant in Hole 5: determinations of the acid-soluble borate in samples from this hole showed that 76 feet of core recovered from the depth interval 1,051 to 1,131 feet averaged above 14 percent of $\mathrm{B}_{2} \mathrm{O}_{3}$. The enclosing lake beds are mineralogically like those contalning calclum borates at the Kramer mining area, containing not only colemanite but the pecullar combination of realgar, a magnet1c 1ron sulflde, and analcime. It seems clear that these beds formed in a lake very simflar to that in whlch Kramer formed, $1 f$ not in the same or a connected lake. 
Outlook for new discoveries

The gealogic studies indicate that borate deposits are to be sought in Tertiary continental sediments in the Besin and Range province. The outcrops in the ranges have been prospected adequately, but extensive blocks of Tertiary rocks concealed below younger alluvial fan and volcanic deposits have not. The outlines of the blocks are Indicated by geologic and gravimetric surveys, but to test them requires drilling. At the present time, substantial private programs of exploratory drilling are underway, and It seems likely that these will make one or more significant additions to our national reserves of borate ore. 
References .

Reports that describe the cores from test boles, and other results of the U. S. Geolocionl Survey borate investigations, aro being prepared for publication. The reports published so far, and those made avallable for public inopetion by plecing them in open f1le, are listed below, preceding an alphabetic 11st of other iltarature cited in this report.

U. S. Ceologicel Survey Bulletin 2045

Ceologle Invest1gations in Mojave Desert and adjecent region, Cal1fornia.

(a) Core loge from Orens, Chlna, Searles, and Pannint basins, Cal1Fornis, by G. I. Sulth and W. P. Pratt 1957. p. 1-62, pl. 1, NG. 1-2.

(b) Core log from two test holes near Braner, san Bermardino County, Californla, by D. D. Dickey. 1957. 63-79, pl. 2, 116. 3.

(c) Core log from Soda Iake, san Bernarulno County, Callfornia, by S. Muessig, G. H. Halte, and F. M. Byers, Jx. 1957. p. 80-96, pl. 3, Ng. 4. 
Beporte in open file

(Ava1lable for inspection at the U. S. Gological survey llbrary, Weshington, D. C.

Geologdc reconnalssance and test-well drflling at Canp

Irw1n, Callfornta, by Fred Kunkel and F. 8. R1ley, 1956, 56 p., 1 pl.

Geologte of the Alvord Mountain quadrangle, Callfornia, by F. M. Byers, Jr., 1956, 1 map, 2 sealogde structure sections.

Geology and petrology of the Iave Mountains, by G. I. Sulth, 1956, 230 p., 59 111us., 15 tables.

Preliminary geologic map of part of the southeastern Mojave Desert, Ban Bernardino County, Callfornla, by D. H. Laperer and A. M. Bassett, 1956.

Core logs trom Searles Ialce, San Bernardino County, by

D. V. Halnes, 2957.

Ground-weter reconnalseance in the western part of the Mojave Desert, Callfornia, with particular respect to the boron content of well water, by R. S. Btone, 1957, 102 p., 13 pls. Slaplifled gealoge mp of the vestern Mojave Desert, Calleornie, by T. W. D1bolee, Jx., 1957. 
Anonymous, 1933, Bortes, in the ninernl 1paluetry of the Britis

Duplre and forelen countries, and ed., 1980-1932, London,

Imperial Inst1tute, p. $20-44$.

Ablfeld, F., and Angrield1, V., 1948, Las Bspectes Mnerales de in Republice Argentina: Univ. Mac. Tucuman, Inst. Cool. y Mn., Jujuy, Pub. 458, p. $162-168$.

Arundale, J. C., 1956, Boron, in Minerul racts and problene: v. 8.

Bur. Anes Bull. 556, p. 137-141.

Arundale, J. C., and Mentch, F. B., 1956, Boron, in Mnernls Yourbook

1953: U. S. Bur. Mines, v. 1, D. 251-260.

Callformia Division of Kines, 1957, Boron: Calle. Div. Mines,

Mineral Information Service, v. 10 , no. 10, p. 1-5.

1958, Mnaral production review, Callfornia, 1957: Callf.

Div. Mines, Mineral Information Service, v. 11, no. 1, p. 8, 9.

Cale, H. S., 1914, Salines in the Orens, Searles and Panamint Basins,

southeastern Callfornia: U. S. Ceol, Survey Bull. 580L, p. 251-323.

1946, Geolosy of the Kramer borate divtrict, Karn County,

Culifornte: Calle. Jour. Mines and Ceology, v. 42, p. 325-378.

Codlevely, M. H., 1937, Hineralogleal Investigation of the Inder Borate

deposits: Manolres de in Soclete Rusee de Mineralogie, IxVI, 2,

p. $315-368$.

Eanks, \&. G., 1883, Report on the borax depossts of Callfornis and

Ilevades Culls. Mn. Bur. Hopt. 3, pt. 2, I1 g.

Hbby, U. F., 1954, Chicene redicactive dates V: Sclence, v. 120,

no. 3123, p. 739 .

Longrnul, C. R., 1949, 8tructure of the Northerr Mudy Mountaln aree,

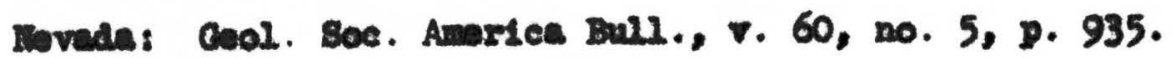


Mason, Brian, 1952, Principles of geochemistry: New York, John Wiley and Sons, p. 41.

Nelixner, HeInz, 1953, New Turkish borste deposits (w1th a general paragenetic classiflcation of all borate minerals): Berg- und Huttenmann. Monatsch montan Leobem. v. 98, p. 86-92.

Miller, B. L., and Singevald, J. T. Jx., 1919, The mineral deposits of South America: New York, MeGraw-Hill Book Co., Inc.

Muessig, Slegfried, and Allen, R. D., 1957, Ecurrite (2ll $\left.20.5 \mathrm{~B}_{2} \mathrm{O}_{3} \cdot 7 \mathrm{H}_{2} \mathrm{O}\right)$,

a new sodium borate from Argentina - occurrence, mineralogy, and associated minerals: Econ. Geology, v. 52, no. 4, p. 426-437.

Noble, L. F., 1941, Structural features of the Virgin Springs area, Death Valley, Callfornia: Geol. Soe. Amerlce Bull., v. 52, p. 941-999. Palache, Charles, Berman, Harry, and Frondel, Clifford, 1951, Dana's system of mineralogy, v. II, Borates: New York, John Wiley and Sons, p. 320-321 and p. 334-368.

Singewald, J. T., Jr., 1943, Blbllography of economic geology of South America: Ceol. Soc. Amerlca Special Paper 50.

Simith, G. I., and Pratt, W. P., 1957, Core log from Ovens, China, Searles, and Panamint Basins, Callfornia: U. S. Ceol. Survey Bull. 1045A.

St1pp, H. E., and Marks, A. L., 1957, Boron, 1n Minerals Yearbook 1955:

v. 8. Bur. Manes, preprint, p. 9-10.

Turrentine, J. W., 1926, Potash, a review, est1mate, and forecast:

John Wiley and Sons, New York, 188 p., quoted in Calle. Div.

Mines, neral Information Service, v. 10, no. 10, p. 1-5.

Ver Planck, W. B., 1956, History of borax production in the United States:

Calif. Jour. Mnes and Geology, v. 52, no. 3, p. 273-291. 
Weld -2548

\author{
UNITED STATES \\ DAPARTNENT OF THE INTERIOR \\ GIOLOGICAL SURVEY \\ Washington, D. C.
}

March 12, 1958

For IMNEDIATE RELEASE

The Goological Survey is releasing in open files the following report. Copy is available for consultation in the Geological Survey Library, 1033 General Services Bldg., Washington, D. C.

Borate deposits of the Mojave region, California, by Ward C. Smith. $30 \mathrm{p}$. 